\title{
PERBANDINGAN SKOR RAMSAY ANESTETIKA INHALASI ISOFULRAN DIBANDING SEVOFLURAN PADA PASIEN PASCA OPERASI ABDOMEN
}

\author{
${ }^{1}$ Muhammad Gufran \\ ${ }^{2}$ Diana Lalenoh \\ ${ }^{2}$ Lucky Kumaat \\ ${ }^{1}$ Kandidat Skripsi Fakultas Kedokteran Universitas Sam Ratulangi \\ ${ }^{2}$ Bagian Anestesiologi Dan Terapi Intensif Fakultas Kedokteran \\ Universitas Sam Ratulangi Manado \\ muhammadgufran032@gmail.com
}

\begin{abstract}
Almost all surgery is performed under anesthesia, and of them performed under general anesthesia. General anesthesia is a reversible condition that changes the physiological status of the body, characterized by sedation, analgesia, amnesia and relaxation. Score ramsay is the first scale that is defined and designed as a measurement tool's ability to wake up. Score ramsay have six different levels of sedation and designed in accordance with how the patient's ability to get up, making it suitable for universal use. This study aims to determine the comparisons between the score ramsay on volatile agent isoflurane and sevoflurane post abdominal surgery in Hospital Prof.Dr.R.D Kandou. The population in this study were patients undergoing abdominal surgery. Twenty eight people were divided into two groups isoflurane and sevoflurane, each consisting 14 people. Data were collected through examination of the level of sedation as measured by post-discontinuation of inhaled agents using ramsay scale. This study found ramsay score on isoflurane higher when compared with sevoflurane in both the 5th minute post-discontinuation and in the 10th minute. There were significant differences between the score ramsay isoflurane and sevoflurane were measured both at the 5th minute post-discontinuation $(\mathrm{p}=0.000)$ and at 10 th minutes $(\mathrm{p}=0.000)$.
\end{abstract}

Keywords: isoflurane, scores ramsay, sedation, sevoflurane.

\begin{abstract}
Abstrak: Hampir semua tindakan pembedahan dilakukan dibawah pengaruh anestesi, dan diantaranya dilakukan dengan anestesi umum. Anestesi umum adalah suatu keadaan reversible yang mengubah status fisiologis tubuh, yang ditandai dengan sedasi, analgesi, amnesi dan relaksasi. Skor ramsay merupakan skala pertama yang didefinisikan dan dirancang sebagai alat ukur kemampuan seseorang untuk bangun. Skor ramsay mempunyai enam tingkat sedasi yang berbeda dan didesain sesuai dengan bagaimana kemampuan pasien untuk bangun, sehingga cocok untuk penggunaan universal. Penelitian ini bertujuan untuk mengetahui perbandingan antara skor ramsay anestetika inhalasi isofluran dan sevofluran paska operasi abdomen di RSU Prof.Dr.R.D Kandou Manado. Populasi dalam penelitian ini ialah pasien yang menjalani bedah abdomen di RSU Prof.Dr.R.D Kandou Manado. Sebanyak 28 orang dibagi dalam dua kelompok yaitu kelompok isofluran dan kelompok sevofluran, yang masing-masing terdiri dari 14 orang. Data dikumpulkan melalui pemeriksaan langsung tingkat sedasi yang diukur paska penghentian agen inhalasi dengan menggunankan skala ramsay. Penelitian ini ditemukan skor ramsay pada anestetika inhalasi isofluran lebih tinggi dibandingkan dengan sevofluran baik pada menit ke-5 paska penghentian agen inhalasi maupun pada menit ke-10. Terdapat perbedaan yang bermakna antara skor ramsay isofluran dan sevofluran yang diukur baik pada menit ke-5 paska penghentian agen inhalasi $(p=0.000)$ maupun pada menit ke-10 ( $\mathrm{p}=0.000)$.
\end{abstract}

Kata kunci : isofluran, skor ramsay, sedasi, sevofluran. 
Hampir semua tindakan pembedahan dilakukan dibawah pengaruh anestesi, dan diantaranya dilakukan dengan anestesi umum. Anestesi umum adalah suatu keadaan reversible yang mengubah status fisiologis tubuh, yang ditandai dengan hilangnya kesadaran (sedasi), hilangnya persepsi nyeri (analgesi), hilangnya memori (amnesi) dan relaksasi. ${ }^{1}$ Eter sebagai anestetik inhalasi pertama yang digunakan, awalnya disiapkan pada tahun 1540 oleh Valerius Cordus. Eter digunakan oleh komunitas medis untuk tujuan sembrono dan tidak digunakan sebagai agen anestesi pada manusia sampai 1842, saat Crawford W. Long dan William E. Clark menggunakannya pada pasien. ${ }^{2}$ Empat tahun kemudian, di Boston, pada 16 Oktober, 1846 William TG Morton melakukan demonstrasi publik pertama anestesi umum menggunakan eter. ${ }^{2}$ Eter masih merupakan standar sampai awal 1960-an walaupun setelah pengenalan anestesi inhalasi lainnya. Agen inhalasi yang dapat bersaing dengan eter ialah siklopropana. ${ }^{2}$ Eter dan siklopropana sangat mudah terbakar dan telah digantikan oleh nonflammable potent fluorinated hydrocarbons antara lain halotan, metoksifluran, enflurane, dan isofluran. Desfluran dan sevofluran merupakan anestetik inhalasi baru yang memiliki banyak sifat baik yang diinginkan dari isofluran serta penyerapan yang cepat dan karakteristik eliminasi nitrous oxide. ${ }^{2}$ Skor ramsay merupakan skala pertama yang didefinisikan dan dirancang sebagai alat ukur kemampuan seseorang untuk bangun. Skor ramsay mempunyai enam tingkat sedasi yang berbeda, pertama kali diperkenalkan oleh Ramsay MAE di tahun 1974. Skor ramsay didesain sesuai dengan bagaimana kemampuan pasien untuk bangun, yang merupakan Skala intuitif, sehingga cocok untuk penggunaan universal, tidak hanya di ICU, tapi di mana pun obat penenang atau narkotika diberikan. $^{3}$ Sevofluran dan Isofluran merupakan dua agent inhalasi yang sering digunakan sebagai maintenance anestesi umum selama operasi. Sevofluran dan isofluran dalam banyak hal mempunyai efek farmakologi yang lebih baik dibanding dengan enfluran dan halothan, dan mempunyai efek samping yang lebih minimal. ${ }^{4}$ Percobaan pada tikus yang dilakukan oleh Edmond I. Eger dan Brynte H. Johnson ${ }^{5}$ menunjukkan bahwa sevofluran memiliki kelarutan dalam darah yang rendah dibandingkan isofluran, oleh sebab itu pemulihan kesadaran setelah anestesi dengan Sevofluran lebih cepat bila dibandingkan dengan isofluran. Penelitian lain yang dilakukan oleh Nobuhiko Yasuda $\mathrm{dkk}^{6}$ menunjukkan bahwa $\mathrm{F}_{\mathrm{A}} / \mathrm{F}_{\mathrm{I}}$ dari sevofluran meningkat dan $\mathrm{F}_{\mathrm{A}} / \mathrm{F}_{\mathrm{A} 0}$ berkurang lebih cepat daripada isofluran pada manusia, tetapi eliminasi dari jaringan tidak berbeda antara sevofluran dan isofluran dan bahwa metabolisme sevofluran tidak berbeda dengan isofluran seperti yang diperkirakan. Penelitian lainnya yang dilakukan oleh Anil Gupta $\mathrm{dkk}^{7}$ ditemukan bahwa early recovery dari Sevofluran lebih cepat bila dibandingkan dengan isofluran.

\section{METODE}

Penelitian dilakukan pada 10 november 2012 hingga 20 desember 2012 di kamar operasi RSU Prof.DR.R.D kandou manado. Sebanyak 28 pasien yang memenuhi kriteria inklusi dilakukan pengukuran tingkat sedasi menggunakan skala ramsay. Berikut kriteria penilaian tingkat sedasi sesuai dengan skala ramsay: ${ }^{3,8,9}$

\begin{tabular}{lc}
\hline \multicolumn{1}{c}{ Kriteria } & Skor \\
\hline $\begin{array}{l}\text { Pasien cemas dan gelisah atau tidak } \\
\text { tenang, atau keduanya }\end{array}$ & 1 \\
$\begin{array}{l}\text { Pasien kooperatif, berorientasi, dan } \\
\text { tenang }\end{array}$ & 2 \\
$\begin{array}{l}\text { Pasien merespon saat diperintah } \\
\text { Pasien menunjukkan respon cepat }\end{array}$ & 4 \\
$\begin{array}{l}\text { untuk sentuhan ringan di glabellar atau } \\
\text { stimulus pendengaran keras }\end{array}$ \\
$\begin{array}{l}\text { Pasien menunjukkan respon yang } \\
\text { lambat untuk sentuhan ringan di }\end{array}$ \\
$\begin{array}{l}\text { glabellar atau stimulus pendengaran } \\
\text { keras }\end{array}$ \\
Pasien menunjukkan tidak ada respon \\
\hline
\end{tabular}




\section{Hasil}

Dari data yang dikumpulkan peneliti pada bulan November 2012 - Desember 2012 berjumlah 28 sampel dengan distribusi sebagai berikut.

Tabel 1. Distribusi jumlah sampel menurut Jenis agen inhalasi

\begin{tabular}{lcl}
\hline Agen inhalasi & Jumlah & Persen \\
\hline Isofluran & 14 & $50 \%$ \\
Sevofluran & 14 & $50 \%$ \\
\hline & 28 & $100 \%$ \\
\hline
\end{tabular}

Tabel 3 Menunjukkan jumlah besar sampel yang diteliti yaitu 28 sampel yang terdiri dari 14 sampel isofluran dan 14 sampel sevofluran.

Tabel 2. Distribusi jumlah sampel menurut Jenis Pembedahan

\begin{tabular}{lcl}
\hline Jenis bedah abdomen & Jumlah & Persen \\
\hline Bedah sesar & 24 & $85.71 \%$ \\
Mioma uteri & 1 & $3.57 \%$ \\
Appendektomi & 2 & $7.14 \%$ \\
Histerektomi & 1 & $3.57 \%$ \\
\hline & 28 & $100 \%$ \\
\hline
\end{tabular}

Tabel 4 Menunjukkan distribusi sampel menurut jenis pembedahan yang dijalani oleh sampel. Bedah sesar merupakan yang terbanyak, yaitu 24 kasus (85.71\%) kemudian diikuti oleh appendektomi sebanyak 2 kasus (7.14\%), dan histerektomi serta Mioma uteri masingmasing sebanyak 1 kasus (3.57\%)

Tabel 3. Distribusi jumlah sampel menurut umur

\begin{tabular}{lll}
\hline Umur (Tahun) & Jumlah & Persen \\
\hline $16-25$ & 6 & $21.43 \%$ \\
$26-35$ & 13 & $46.43 \%$ \\
$36-45$ & 8 & $28.57 \%$ \\
$46-55$ & 1 & $3.57 \%$ \\
$56-65$ & 0 & $0.00 \%$ \\
\hline & 28 & $100.00 \%$ \\
\hline
\end{tabular}

Tabel 5 Menunjukkan distribusi sampel menurut kelompok umur. kelompok umur yang paling banyak berada di kelompok umur 26-35 tahun (46.43\%), kemudian kelompok umur 36-45 tahun (28.57\%), lalu kelompok umur 16-25 tahun (21.43\%), dan kelompok umur 46-55 tahun (3.57\%). Tidak didapati sampel yang berada di kelompok umur 56-65 tahun.

Tabel 4. Rata - rata umur Kelompok Isofluran dan Sevofluran

\begin{tabular}{lcc}
\hline & Mean & N \\
\hline Umur Kelompok Isofluran & 31.43 & 14 \\
Umur Kelompok & 32.93 & 14 \\
Sevofluran & & \\
\hline
\end{tabular}

Tabel 6 menunjukkan rerata umur kelompok isofluran dan sevofluran. Terlihat ada sedikit perbedaan antara kedua kelompok yang dibandingkan tersebut.

Tabel 5. Uji Statistik perbedaan umur kelompok isofluran dan sevofluran

\begin{tabular}{lc}
\hline & \multicolumn{2}{c}{ P } \\
\hline Umur & Kelompok \\
Isofluran - & \\
Umur & Kelompok \\
Sevofluran & \\
\hline *Di uji dengan uji statistik T-tes
\end{tabular}

Tabel 7 menunjukkan hasil uji statistic antara dua kelompok yang dibandingkan. Dari hasil uji statistik, didapatkan tidak ada perbedaan bermakna untuk usia pada kedua kelompok yang dibandingkan $(\mathrm{p}=0.701)$. Dengan demikian dapat diasumsikan bahwa kedua kelompok yang diteliti relatif homogen ditinjau dari segi usia sampel.

Tabel 8 menunjukkan rerata lama operasi antara dua kelompok yang dibandingkan dalam menit. Terlihat ada sedikit perbedaan antara kedua kelompok yang dibandingkan tersebut. 
Tabel 6. Rata-rata lama operasi kelompok isofluran dan sevofluran

\begin{tabular}{lcl}
\hline & Mean & $\begin{array}{l}\text { Std. } \\
\text { Deviation }\end{array}$ \\
\hline $\begin{array}{l}\text { Lama Operasi } \\
\begin{array}{l}\text { Kelompok Isofluran } \\
\text { Lama Operasi }\end{array}\end{array}$ & 83.57 & 17.145 \\
$\begin{array}{l}\text { Kelompok Sevofluran } \\
84.29\end{array}$ & 15.794 \\
\hline
\end{tabular}

Tabel 7. Uji statistik perbedaan lama operasi kelompok isofluran dan sevofluran

\begin{tabular}{ll}
\hline & P \\
\hline Lama Operasi Kelompok & \\
Isofluran - & $.915^{*}$ \\
Lama Operasi Kelompok & \\
$\quad$ Sevofluran & \\
*Di uji dengan uji statistik T-tes
\end{tabular}

Tabel 9 menunjukkan hasil uji statistik antara dua kelompok yang dibandingkan. Dari hasil uji statistik, didapatkan tidak ada perbedaan bermakna untuk lama operasi pada kedua kelompok yang dibandingkan ( $\mathrm{p}=0.915)$. Dengan demikian dapat diasumsikan bahwa kedua kelompok yang diteliti relatif homogen ditinjau dari lama operasi.

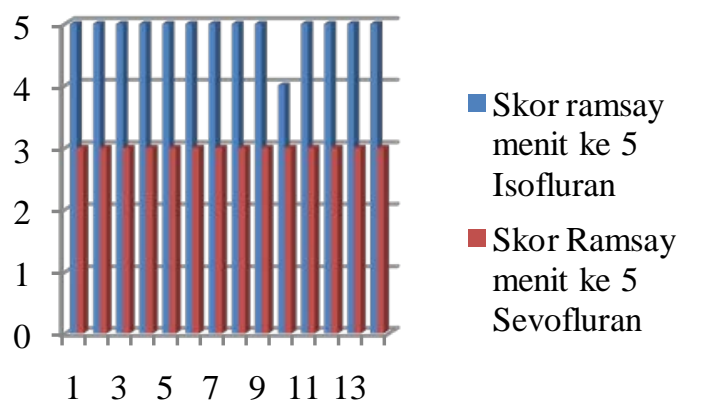

Gambar 1. Skor ramsay menit ke 5 Isofluran dan sevofluran

Gambar 1 menunjukkan skor ramsay pada menit ke 5 anestetika inhalasi isofluran dan sevofluran. Terlihat bahwa secara keseluruhan skor ramsay pada anestetika inhalasi isofluran lebih tinggi bila dibanding dengan sevofluran.
Tabel 8. Rata-rata skor ramsay menit ke 5

\begin{tabular}{lc}
\hline Skor Ramsay & \multicolumn{1}{c}{ Rata-rata } \\
\hline $\begin{array}{l}\text { Skor Ramsay Isofluran Menit } \\
\text { ke-5 }\end{array}$ & \\
$\begin{array}{l}\text { Skor Ramsay Sevofluran } \\
\text { Menit ke-5 }\end{array}$ & 3.00 \\
\hline
\end{tabular}

Tabel 10 Menunjukkan rata-rata skor ramsay anestetika inhalasi isofluran dan sevofluran yang dinilai pada menit ke-5 . Terlihat sekilas bahwa terdapat perbedaan yang signifikan antara kedua variabel tersebut.

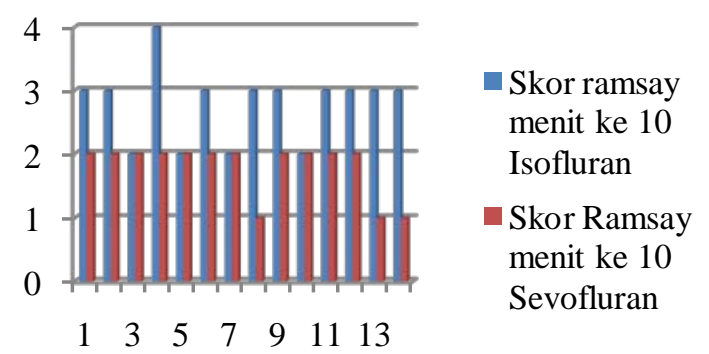

Grafik 2. Skor ramsay menit ke 10 Isofluran dan Sevofluran.

Grafik 2 menunjukkan skor ramsay pada menit ke 10 anestetika inhalasi isofluran dan sevofluran. Terlihat bahwa secara keseluruhan skor ramsay pada anestetika inhalasi isofluran lebih tinggi bila dibanding dengan sevofluran.

Tabel 9. Rata - rata skor ramsay menit ke 10

\begin{tabular}{ll}
\hline Skor ramsay & Rata - rata \\
\hline $\begin{array}{l}\text { Skor Ramsay Isofluran } \\
\text { Menit ke-10 }\end{array}$ & 2.79 \\
$\begin{array}{l}\text { Skor Ramsay Sevofluran } \\
\text { Menit ke-10 }\end{array}$ & 1.79 \\
\hline
\end{tabular}

Tabel 11 Menunjukkan rata-rata skor ramsay anestetika inhalasi isofluran dan sevofluran yang dinilai pada menit ke-10 . Terlihat sekilas bahwa terdapat perbedaan yang signifikan antara kedua variabel tersebut. 
Tabel 10. Skor ramsay menit ke 5 dan 10

\begin{tabular}{ll}
\hline Skor Ramsay & Rata - rata \\
\hline $\begin{array}{l}\text { Skor Ramsay Isofluran Menit } \\
\text { ke-5 }\end{array}$ & 4.93 \\
$\begin{array}{l}\text { Skor Ramsay Sevofluran } \\
\text { Menit ke-5 }\end{array}$ & 3.00 \\
$\begin{array}{l}\text { Skor Ramsay Isofluran Menit } \\
\text { ke-10 }\end{array}$ & \\
$\begin{array}{l}\text { Skor Ramsay Sevofluran } \\
\text { Menit ke-10 }\end{array}$ & 1.79 \\
\hline
\end{tabular}

Tabel 12 Menunjukkan rata-rata skor ramsay anestetika inhalasi isofluran dan sevofluran yang dinilai pada menit ke-5 dan ke-10. Terlihat sekilas bahwa terdapat perbedaan yang signifikan antara rata-rata skor ramsay anestetika inhalasi isofluran dan sevofluran yang dinilai pada menit ke5, dan juga terlihat perbedaan rata-rata skor ramsay yang dinilai pada menit ke-10.

Tabel 11. Analisis perbandingan rata - rata skor ramsay

\begin{tabular}{lc}
\hline & P \\
\hline Skor Ramsay Menit 5 Isofluran - & $.000 *$ \\
Skor Ramsay Menit 5 Sevofluran & \\
Skor Ramsay Menit 10 Isofluran - & $.000 *$ \\
Skor Ramsay Menit 10 Sevofluran & \\
\hline *Di uji dengan uji statistik T-tes &
\end{tabular}

Tabel 13 Menunjukkan adanya perbedaan yang bermakna dari skor ramsay pada menit ke-5 antara isofluran dan sevofluran $(\mathrm{p}=0.000)$. Demikian pula terlihat ada perbedaan bermakna dari skor ramsay menit ke-10 antara isofluran dan sevofluran $(p=0.000)$.

\section{DISKUSI}

Berdasarkan data yang diperoleh dari OK RSUP Prof. Kandou manado, didapati jumlah sampel penelitian sejumlah 28 sampel . penelitian dan pengambilan sampel dilakukan pada bulan November 2012 - Desember 2012.

Dari sampel tersebut, dibagi 2 kelompok yaitu kelompok isofluran dan sevofluran. Masing- masing kelompok terdiri dari 14 sampel yang berbeda. Pada analisis deskriptif terlihat bahwa ada perbedaan antara rata-rata skor ramsay isofluran dengan skor ramsay sevofluran, dan kemudian dilakukan uji statistik dengan uji kemaknaan T-tes dan didapatkan perbedaan tersebut signifikan.

Hasil dari uji statistik yang dilakukan sebagai dasar pengambilan keputusan (berdasarkan probabilitas) pada $\mathrm{p}<0.15$ terlihat bahwa angka signifikansi perbandingan skor ramsay isofluran dibanding sevofluran pada menit ke-5 adalah 0,000 dan juga pada menit ke-10 adalah 0,000 . Hal ini berarti ada perbedaan yang bermakna antara skor ramsay isofluran dibanding sevofluran pada menit ke-5 maupun pada menit ke-10.

Penyebab perbedaan bermakna setelah dilakukan uji statistik pada penelitian ini dikarenakan farmakokinetika dan farmakodinamika yang berbeda dari kedua agen inhalasi tersebut. Dimana secara farmakologis, sevofluran lebih unggul dalam hal induksi dan eliminasi dari jaringan bila dibandingkan dengan isofluran., ${ }^{6,10}$

Pemulihan dari anestesi umum tergantung pada sejumlah faktor termasuk durasi anestesi, fisika-kimia dari agen anestesi (kelarutan dan protein pengikat), dan tingkat metabolisme dan/atau ekskresi. Lamanya anestesi dan kelarutan anestesi dalam darah merupakan penentu utama dari durasi efek anestesi untuk agen inhalasi. Pasien yang teranestesi dengan isofluran selama kurang dari satu jam membuka mata mereka pada perintah yang rata-rata 7.3 menit setelah penghentian anestesi. ${ }^{11}$ Waktu pemulihan meningkat $65 \%$ pada pasien yang dianestesi selama dua sampai tiga jam, namun, eksposur lebih lama tidak memperpanjang waktu pemulihan. ${ }^{11}$

Dari hasil penelitian ditemukan bahwa skor ramsay sevofluran lebih cepat mendekati nilai 1 bila dibandingkan dengan isofluran. Hal serupa didapatkan juga pada penelitian yang dilakukan oleh Beverly $\mathrm{K}$. Philip $\mathrm{dkk}^{12}$. Penelitian yang dilakukan oleh Beverly K. Philip $\mathrm{dkk}^{12}$ tentang perbandingan antara sevofluran dan 
isofluran menunjukkan Pasien yang menerima sevofluran, untuk pemeliharaan sadar lebih cepat dari mereka yang diberi isofluran. Perbedaan ini hadir pada pembukaan mata dan untuk indikator pemulihan awal dari respon perintah dan orientasi. Perbedaan juga hadir pada satu jam pertama pasien sevofluran, ketika mereka mampu untuk duduk lebih awal tanpa mual atau pusing. Rata-rata pasien yang teranestesi menggunakan sevofluran dapat membuka mata pada menit ke 7 dan membuka mata pada menit ke 9 dengan isofluran.

Skor ramsay yang lebih tinggi pada isofluran sesudah agen inhalasi dihentikan baik pada menit ke-5 maupun menit ke-10 yang ditemukan pada penelitian ini kemungkinan berkaitan dengan sifat-sifat farmakologis yang dimiliki oleh masingmasing inhalan tersebut.

Pemulihan dari anestesi tergantung pada penurunan konsentrasi anestesi di jaringan otak. Eliminasi dapat terjadi melalui biotransformasi, kehilangan transkutan, atau pernafasan. Rute yang paling penting bagi eliminasi agen inhalasi adalah melalui pernafasan. ${ }^{2}$ Banyak faktor yang mempengaruhi kecepatan induksi juga mempercepat pemulihan. Konsentrasi terinspirasi dan kelarutan gas;darah (blood:gas partition) anestesi inhalasi merupakan penentu utama dari kecepatan induksi. Kelarutan sendiri menentukan tingkat eliminasi agen inhalasi. ${ }^{4}$ Koefisien partisi darah/gas sevofluran $(0,65)$, lebih rendah dibandingkan dengan isofluran (1.4) hal ini mengindikasikan bahwa sevofluran lebih sukar larut di dalam darah, bila dibandingkan dengan isofluran. ${ }^{2,4,13}$ Oleh karena itu eliminasi sevofluran akan lebih cepat bila dibandingkan dengan isofluran. Eliminasi dari jaringan otak juga tergantung pada tekanan parsial agen inhalan di alveolus. Pada keadaan ekuilibrium, tekanan parsial gas agen inhalan baik di sistem saraf pusat, darah maupun di alveolus adalah sama. ${ }^{4}$ Maka penurunan tekanan parsial gas pada alveolus akan berdampak langsung terhadap tekanan parsial gas di sistem saraf pusat, dengan demikian agen inhalasi seperti sevofluran yang mempunyai kelarutan yang rendah dalam darah akan lebih cepat dalam hal peningkatan dan penurunan tekanan parsial gas baik di alveolus, darah, maupun di sistem saraf pusat yang berarti bahwa pemulihan kesadaran juga akan lebih cepat tercapai pada sevofluran dibandingkan dengan isofluran. Hal ini sesuai dengan hasil penelitian yang dilakukan oleh Thomas J. Ebert $\mathrm{dkk}^{14}$ dimana pemulihan kesadaran lebih cepat tercapai (3-4 menit lebih cepat) pada kelompok sevofluran bila dibandingkan dengan isofluran dalam semua kelompok umur.

\section{SIMPULAN}

Terdapat perbedaan yang bermakna $(p=0.000)$ antara rata-rata skor ramsay pada anestetika inhalasi isofluran dibanding sevofluran pada menit ke 5 paska penghentian agen inhalasi. Rata-rata skor ramsay pada anestetika inhalasi isofluran lebih tinggi (4.93) dibanding sevofluran (3.00) pada menit ke-5 paska penghentian agen inhalasi.

Terdapat perbedaan yang bermakna $(\mathrm{p}=0.000)$ antara Rata-rata skor ramsay pada anestetika inhalasi isofluran dibanding sevofluran pada menit ke 10 paska penghentian agen inhalasi. Rata-rata skor ramsay pada anestetika inhalasi isofluran lebih tinggi (2.79) dibanding sevofluran (1.79) pada menit ke-10 paska penghentian agen inhalasi.

Ucapan terimakasih penulis haturkan kepada penguji I dan II yang telah banyak memberi masukan dan ide-ide dalam penulisan artikel ini. Penulis juga menucapkan banyak terima kasih kepada seluruh pihak baik yang secara langsung maupun tidak langsung telah menumbuhkan ide-ide kepada penulis sehingga artikel ini bisa rampung.

\section{DAFTAR PUSTAKA}

1. Holder A. Sedation. Diunduh dari: http:// emedicine.medscape.com/ article/ 809993- 
overview\#showall Diakses : Agustus 2012

2. Morgan GE, Mikhail MS, Murray MJ. Morgan's Clinical Anesthesiology. 4th ed. USA: Appleton \& Lange; 2006.

3. Ramsay MAE, Savege TM, Simpson BRJ \& Goodwin R. Controlled sedation with alpaxalone-alphadolone. British Medical Journal 1974; 2: 656 - 659.

4. Ebert TJ, Schmid PG. Inhaled Anesthetic. In: Barash GP, Cullen BF, Stoelting RK, Calahan MK, Stock MC. Clinical Anesthesia. $6^{\text {th }}$ ed. Philadelphia: Lippincott Williams \& Wilkins; 2009;415-43.

5. Eger EI, Johnson BH. Rates of awakening from anesthesia with 1-653, halothane, isoflurane, and sevoflurane: A test of the effect of anesthetic concentration and duration in rats. ANESTH ANALG. 1987;66:977-82

6. Yasuda N, Lockhart SH, Eger II EI, Weiskopf RB, Liu J, Laster M, et al. Comparison of kinetics of sevoflurane and isoflurane in humans. ANESTH ANALG. 1991;72:31\&24

7. Gupta A, Stierer T, Zuckerman R, Sakima N, Parker SD, Fleisher LA. Comparison of recovery profile after ambulatory anesthesia with propofol, isoflurane, sevoflurane and desflurane: A systematic review. ANESTH ANALG. 2004; 98:632-41

8. Jonghe BD, Cook D, Appere-De-Vecchi C, Guyatt G, Meade M, Outin H. Using and understanding sedation scoring systems: a systematic review. Intensive Care Med. 2000; 26: 275 \pm 285

9. Stawicki SP. ICU corner Sedation scales: Very useful, very underused. OPUS 12 Scientist. 2007;Vol. 1, No. 2: 10-12

10. Arar C, Kaya G, Karamanliog lu B, Pamukçu Z, Turan N. Effects of sevoflurane, isoflurane and propofol infusions on post-operative recovery criteria in geriatric patients. The Journal of International Medical Research. 2005; 33: $55-60$

11. Milam SB. General anesthetics: a comparative review of pharmacodynamics. ANESTHESIA PROGRESS. 1984; 116123

12. Philip BK, Kallar SK, Bogetz MS, Scheller MS, Wetchler BV. A multicenter comparison of maintenance and recovery with sevoflurane or lsoflurane for adult ambulatory anesthesia. Anesth Analg.1996;83:314-9

13. Evers AS, Crowder CM. Mechanisms of Anesthesia and Consciousness. In: Barash GP, Cullen BF, Stoelting RK, Calahan MK, Stock MC. Clinical Anesthesia. $6^{\text {th }}$ ed. Philadelphia: Lippincott Williams \& Wilkins; 2009;97-110.

14. Ebert TJ, Robinson BJ, Uhrich TD, Mackenthun A, Pichotta PJ. Recovery from sevoflurane anesthesia, A comparison to isoflurane and propofol anesthesia. anesthesiology.1998;89.1524-31 